\title{
The Effects of Race/Ethnicity, Age, and Area Deprivation Index (ADI) on COVID-19 Disease Early Dynamics: Washington, D.C. Case Study
}

\author{
Sarah Adjei-Fremah ${ }^{1}$ (D) Niara Lara ${ }^{2} \cdot$ Azreen Anwar $^{2} \cdot$ Daneila Chala Garcia $^{2} \cdot$ SeyyedPooya Hemaktiathar $^{2} \cdot$ \\ Chinenye Blessing Ifebirinachi ${ }^{2} \cdot$ Mohd Anwar $^{2} \cdot$ Feng-Chang Lin $^{3} \cdot$ Raymond Samuel $^{2}$
}

Received: 13 August 2021 / Revised: 23 December 2021 / Accepted: 10 January 2022 / Published online: 15 February 2022

(c) W. Montague Cobb-NMA Health Institute 2022

\begin{abstract}
The COVID-19 pandemic and its associated mitigation strategies have significant psychosocial, behavioral, socioeconomic, and health impacts, particularly in vulnerable US populations. Different factors have been identified as influencers of the transmission rate; however, the effects of area deprivation index (as a measure of social determinants of health, $\mathrm{SDoH}$ ) as a factor on COVID-19 disease early dynamics have not been established. We determined the effects of area deprivation index (ADI) and demographic factors on COVID-19 outcomes in Washington, D.C. This retrospective study used publicly available data on COVID-19 cases and mortality of Washington, D.C., during March 31st-July 4th, 2020. The main predictors included area deprivation index (ADI), age, and race/ethnicity. The ADI of each census block groups in D.C. ( $n=433)$ were obtained from Neighborhood Atlas map. Using a machine learning-based algorithm, the outcome variables were partitioned into time intervals: time duration $\left(\mathrm{P}_{\mathrm{i}}\right.$, days), rate of change coefficient $\left(\mathrm{E}_{\mathrm{i}}\right)$, and time segment load $\left(\mathrm{P}_{\mathrm{i}} \times \mathrm{E}_{\mathrm{i}}\right)$ for transmission rate and mortality. Correlation analysis and multiple linear regression models were used to determine associations between predictors and outcome variables. COVID-19 early transmission rate $\left(\mathrm{E}_{1}\right)$ was highly correlated with ADI (SDoH; $r=0.88$, $p=0.0044)$ of the Washington, D.C. community. We also found positive association between ADI, age ( $0-17$ years, $r=0.91$, $p=0.0019$ ), and race (African American/Black, $r=0.86 ; p=0.0068$ ) and COVID-19 outcomes. There was high variability in early transmission across the geographic regions (i.e., wards) of Washington, D.C., and this variability was driven by race/ ethnic composition and ADI. Understanding the association of COVID-19 disease early transmission and mortality dynamics and key socio-demographic risk factors such as age, race, and ADI, as a measure of social determinants, will contribute to health equity/equality and distribution of economic resources/assistance and is essential for future predictive modeling of the COVID-19 pandemic to limit morbidity and mortality.
\end{abstract}

Keywords COVID-19 pandemic $\cdot$ Social determinants $\cdot$ Race/ethnicity $\cdot$ Age $\cdot$ Disparity $\cdot$ Area deprivation index $\cdot$ Case study

\section{Introduction}

The coronavirus disease 2019 (COVID-19) caused by the SARS-CoV-2 (severe acute respiratory syndrome coronavirus) is a global pandemic and health emergency with impact on the

Sarah Adjei-Fremah

adjeifremahs@wssu.edu

1 Winston-Salem State University, Winston-Salem, NC, USA

2 North Carolina Agricultural and Technical State University, Greensboro, NC, USA

3 University of North Carolina at Chapel Hill, Chapel Hill, NC, USA
USA. As of August 10th, 2020, out of 19,919,559 confirmed cases globally, 5,058,464 have occurred in the United States (US) [1]. In the US, Washington, D.C., is a major focus due to the intersectionality of its municipal and federal government. Different factors have been identified as influencers of the transmission rate and the impact of the virus [2-4]. This global pandemic has highlighted the disparities in health, and the opportunity to address these underlying inequalities especially in vulnerable populations and groups [5]. Daily COVID-19 prevalence and mortality estimate in different geographic areas in the USA show a consistent pattern of racial/ ethnic differences. A recent US Center for Disease Control and Prevention (CDC) report found that Black and Hispanic children are more likely to be hospitalized due to coronavirus 
than non-Hispanic White (NHW) children. More specifically, Hispanic children had highest coronavirus hospitalization rate of 16.4 per 100,000 people, followed by Black children at 10.5 per 100,000 compared to 2.1 per 100,000 in NHW children. This was based on hospitalization record from 14 states dated March through July 4 [6].

In terms of mortality, African American and Latino communities experience non-disproportionately higher mortality rate compared to non-Hispanic White communities, even though these groups comprise only $13 \%$ and $18 \%$ of the US population, respectively [6]. The mortality rate for COVID-19 among African Americans (80.4 deaths per 100,000) is more than 2-fold higher than Whites (35.9 deaths per 100,000). The age-adjusted COVID-19 mortality rate is 3.7 times higher in Black Americans compared with Whites. In majority of the reported states including Washington, D.C., African Americans comprise higher proportion of deaths relative to their percentage in those jurisdictions' population [7].

Social determinants of health drive $80 \%$ of population health outcomes. According to the health equity report for D.C., some of the key social determinants of health include income, education, housing, employment, and transportation [8, 9]. Area depravation index (ADI) is a measure of social determinants which factors in domains of income, education, employment, and housing quality [10]. ADI provides an area-based measure of how socioeconomically deprived residents of that area are on average $[11,12]$. The ADI has been associated with increased prevalence of adverse health and healthcare outcomes including community incidence of COVID-19 in a US metropolis [10, 13-15].

As more COVID-19 daily incidence and mortality data emerge, it is important to understand the complex underlying causes of health disparities including social determinants of health, economic and educational disadvantages, healthcare access, and quality. A more comprehensive analysis of potential determinants (mediators and moderators) might explain the associations between vulnerability and health disparities that cut across multiple levels [16]. The objective of this study was to assess the relationships between area deprivation index (ADI, a measure of social determinant), demographic and healthcare services characteristics, and COVID-19 transmission and mortality rates in D.C. wards (neighborhoods) and in the surrounding counties in Virginia and Maryland (Fig. 1).

\section{Materials and Methods}

\section{Data Collection, Measures, and Analysis}

\section{COVID-19 Data Source for Washington, D.C., and Adjacent Counties}

The publicly available COVID-19 confirmed case count data, including daily confirmed (laboratory confirmed)

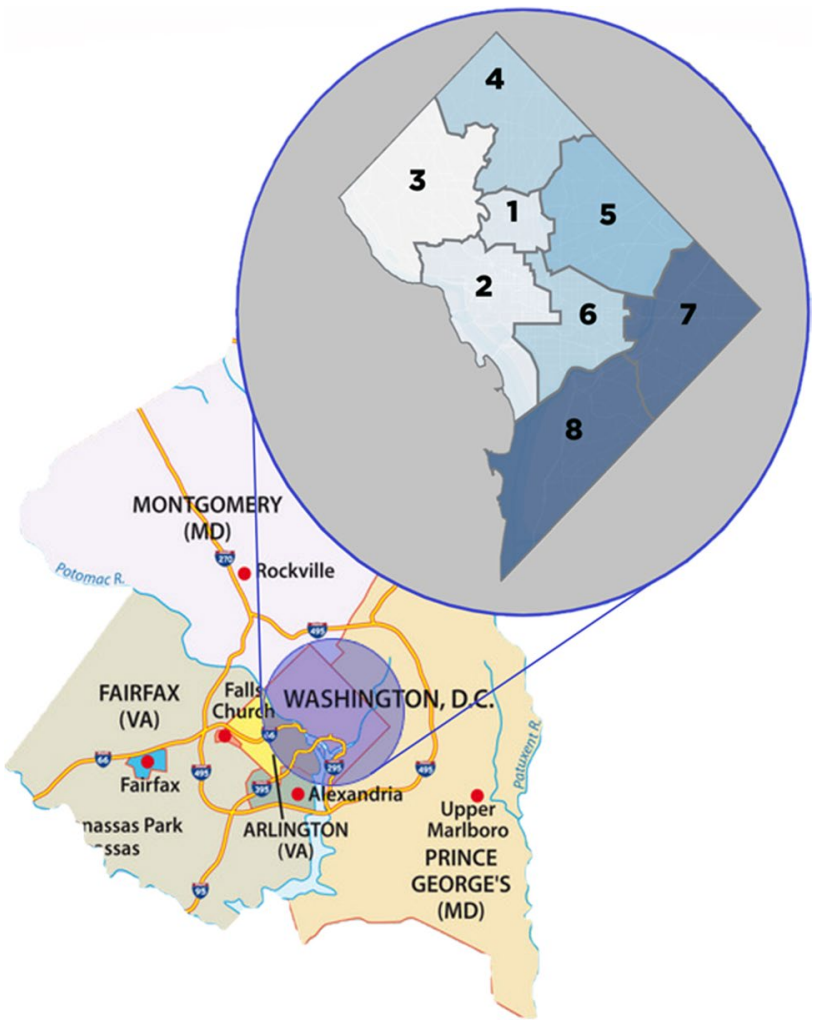

Fig. 1 Map of Washington, D.C., at ward level and adjacent counties in Virginia and Maryland

cases, and death data were collected from the Center for Systems Science and Engineering (CSSE) Coronavirus Resource Center at the Johns Hopkins University. COVID19 case numbers (morbidity) and deaths (mortality) data for Washington, D.C., at ward level (neighborhoods) and selected adjacent counties Prince George's County (MD), Montgomery County (MD), Fairfax County (VA), Arlington (VA), and Alexandria City (VA) were collected from March 31st through July 4th, 2020.

Cross-sectional Data The COVID-19 confirmed cases and deaths collected were readjusted to the ratio of the number of COVID-19 cases/death to population size for 100,000 people as previously described [17]. Therefore, the cases and deaths are presented in Table 1 as per 100,000 people. The case fatality rate (i.e., number of death/total number of confirmed cases) was calculated for the D.C./county level and D.C. ward level.

\section{Data Sources for Covariates}

Area Deprivation Index Data Area deprivation index (ADI) data for D.C. were obtained from already computed ADI scores from the Neighborhood Atlas [10] as previously 


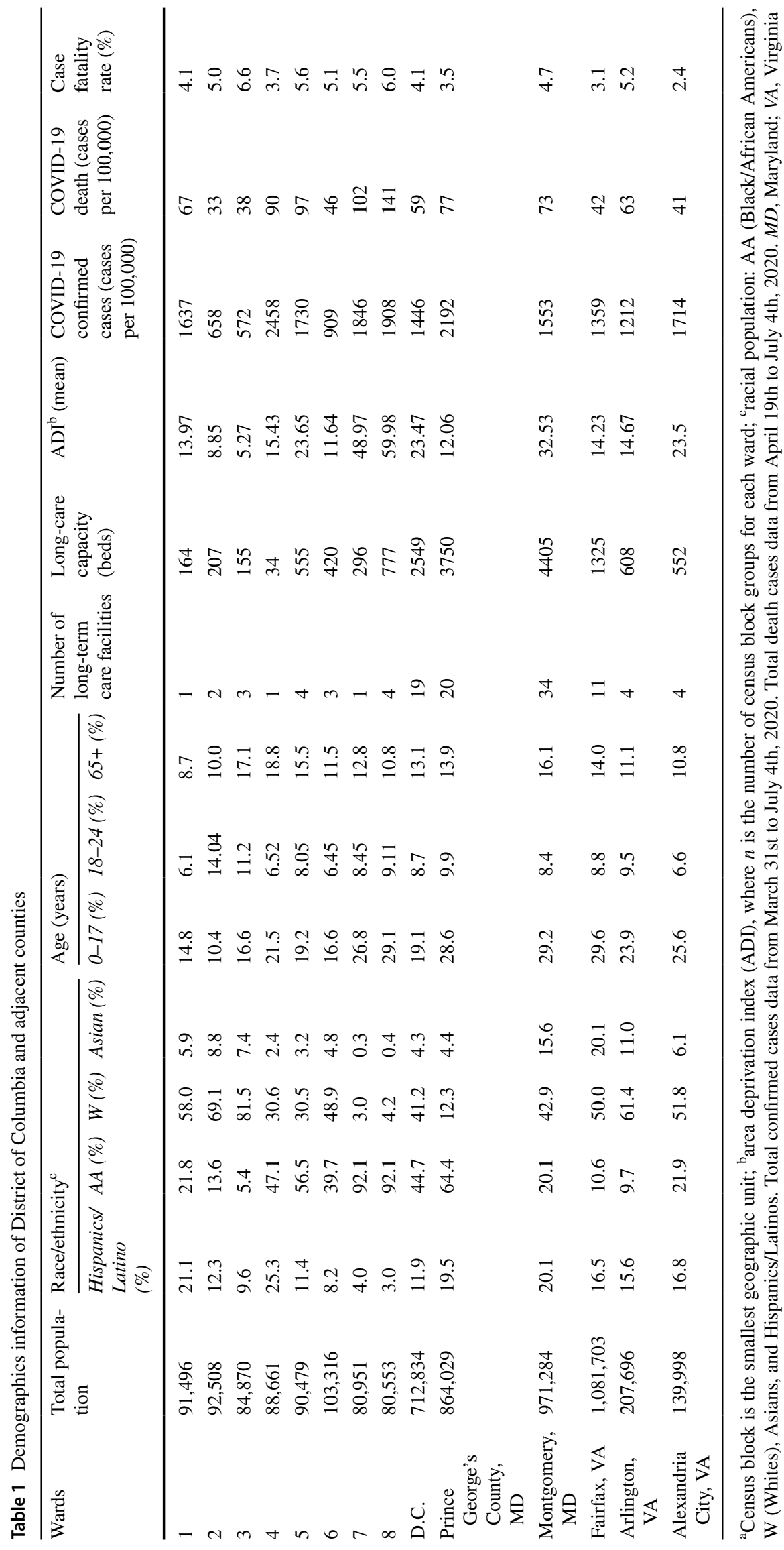


described by Knighton et al. [18] and Singh [19]. The ADI data was collected for census block group (BG) for each D.C. ward. A census block is the smallest geographic unit and according to the US Census Bureau geographic terms and concepts, the BGs have unique numerical identity within the census tract, and they never cross state, county, or census tract boundaries. Washington, D.C., is divided into eight wards, each with different population size and varying demographics [13]. Each neighborhood is assigned a ranking based on the ADI [10]. The D.C. wards with a higher ADI ranking are most disadvantaged. The ADI national composite scale (1-100) where $1-10$ is least disadvantaged and $90-100$ is most disadvantaged as described previously $[18,19]$. The ADI data were collected on the D.C. census block groups (BG; $n=433$ ) as of 2013 as shown in Table 1 . We superimposed the block-level map with the ward division map using neighborhoods as landmarks. The ADI for the BGs (average) were aggregated at the D.C. ward levels. Similarly, we obtained the ADI for Prince George's County, MD (total census blocks=515), Montgomery County, MD (total census blocks=185), Fairfax County, VA (total census blocks=659), Arlington, VA (total census blocks=176), and Alexandria City (total census blocks=105).

Demographic Data Demographic data collected from DC Health Matters (www.dchealthmatters.org) were used. The population age group structure data were gathered for 0-17 years, 18-24 years, and 65 years at the ward level. Data on racial/ethnic distribution for each ward was collected for Latino/Hispanics, African Americans/Blacks (AA), nonHispanic Whites, and Asians.

Healthcare Services Data Data on number of beds in longterm care nursing facilities in each D.C. ward was collected from DC Health Matters (www.dchealthmatters.org). There are a total of 18 long-term care nursing facilities in D.C., where wards 1,4 , and 7 have 1 facility each; wards 2 and 3 have 2 facilities each; ward 6 has 3 ; and wards 5 and 8 each have 4 facilities. The total number of beds at the ward level was tallied as presented in Table 1.

\section{Outcome Variables Analysis}

An algorithm for data-driven phasic model was developed and used to efficiently capture the transmission time series/ points $\left(\mathrm{P}_{\mathrm{i}}\right.$; duration) and transmission coefficient $\left(\mathrm{E}_{\mathrm{i}}\right)$ and time segment load $\left(R_{0}\right)$ with an $R^{2}$ of $90 \%$ or more. The commonly used models for longitudinal data selection include Akaike information criterion (AIC) and the Bayesian information criterion (BIC) [20, 21]. In the current study, we performed time-series segmentation using a computational algorithm. The goal of this algorithm was to segment time series of transmission into multiple time points/duration
$\left(\mathrm{P}_{\mathrm{i}} ; \mathrm{P}_{1}, \mathrm{P}_{2}, \mathrm{P}_{3}, \ldots\right.$, etc.), i.e., change in transmission rate as function of duration; and transmission coefficient $\left(\mathrm{E}_{\mathrm{i}}\right)$ for COVID-19 morbidity and mortality rates. We also estimated the time segment load/ratio $\left(R_{0}\right)$ as the product of $\mathrm{P}_{\mathrm{i}}$ and $\mathrm{E}_{\mathrm{i}}$. This data segmentation algorithm identifies the points at which the behavior of the curve changes, i.e., the slope of the transmission rate changes. In this process, the segmentation was done by the following steps: (1) taking natural log values for our dependent variable to linearize the model; (2) taking the third derivative and marking the points where the third derivative changes sign; (3) fitting a linear regression to the data points between each consecutive marked point; (4) finding the two lines with the least difference in slope. If merging these two lines results in an $R^{2}$ value higher than the threshold, merge them and go to step 3 . Else, the process ends. The $R^{2}$ value in step 4 is calculated after raising both prediction and ground truth to the power of 10 to remove the effect of log. The threshold was determined by matching the algorithm's output with human expert's assessment.

\section{Statistical Analysis}

Statistical data analysis was done using JMP statistical software, version 15.0 [22] (SAS Institute Inc., Cary, NC, 1989-2019). Descriptive statistical analysis was performed to characterize the predictors and outcome variables of the study and the results are presented in supplementary tables. The continuous variables were summarized as mean, standard deviation (SD), standard error of the mean (SE), 95\% confidence interval (CI), $75 \%$ quartile, $25 \%$ quartile $(\mathrm{Q})$, and interquartile range (IQR). The association between predictors (ADI, age, race/ethnicity, long-term care facility capacity (number of beds), and outcome variables (transmission and mortality)) were measured using correlation analysis and the results are presented as correlation coefficients. Based on the individual predictors' association with outcome variables, further analysis was done using multiple linear regression. Multiple linear regression analyzed the covariates influencing the COVID-19 transmission outcome variables for D.C. ward level. All assumptions and conditions of the linear regression model have been addressed in the analysis (normality of residuals, linearity, and homoscedasticity). Bivariate density ellipse analysis at 0.95 was done to check the linearity of the covariates (correlation coefficient of $<0.20$ cutoff). The covariates ages 18-24 and 65, number of beds, and number of long-term care facilities were excluded from the analysis based on the cutoff. The multiple linear regression was performed with the standard least square method using backward selection using all the covariates that satisfied the assumptions of the analysis. The statistical significance was tested at $p<.05$. 


\section{Results}

\section{Washington, D.C. Demographic Description}

The District of Columbia is geographically divided into 8 wards and the detailed population demographic is presented in Table 1. Out of the 712,834 total D.C. population, $44.7 \%$ are African Americans, $41.2 \%$ are Whites, and $11.9 \%$ are Latinos/Hispanics.

Predictor Variables The predictors in this study include ADI, age structure (0-17, 18-24, and 65+ years), and race/ ethnic distribution. Table 2 presents the summary of descriptive statistics of the predictor variables. The ADI means for each ward in D.C. range from 5.027 to 59.98 with ward 3 having lowest ADI and ward 8 has the highest. The average ADI for Washington, D.C., was 23.47 (SD = 20.08), and $t$-test analysis results showed significant variation in ADI $(t(\mathrm{df}=7)=6.48 ; p=0.0003)$ among the D.C. wards as reported in Table 1. More disadvantaged wards are those with a higher ADI score.

Age Structure The average age structure for D.C. includes 0-17 (19.37\%, SD = 6.34), 18-24 (8.74\%, SD = 2.73), and $\geq 65$ years $(13.14 \%, \mathrm{SD}=3.60)$. There are statistically significant population variations in age structure among the wards for $0-17(t(\mathrm{df}=7)=8.48, p<.0001), 18-24(t(\mathrm{df}=7)$ $=9.07 p<.0001)$, and 65 years $(t(\mathrm{df}=7)=10.32, p<.0001)$ as presented in Table 3 . Ward 8 has the highest $0-17$ age group population $(29.1 \%)$, whereas ward 2 has the lowest $(10.4 \%)$. A greater majority of 65 age group are found in ward $3(18.8 \%)$, and ward 1 has the least population (8.7\%) of 65 age group residents in D.C. The D.C. population age distribution and ADI at the ward level are presented in Table 1.

Race/Ethnic Distribution The highest concentration of Nonhispanic Whites $(81.5 \%)$ is in ward 3 with mean ADI of 3.4 , whereas the greater proportion of African Americans lives in ward $7(92.1 \%)$ and ward 8 (92.1\%) with ADI scores of 48.97 and 59.98, respectively. The other minority racial population groups such as Asians and Latinos/Hispanics also live in different wards.

COVID-19 Outcome Variables Figure 2 presents (a) the time point/duration of disease spread $\left(\mathrm{P}_{1}, \mathrm{P}_{2}\right.$, and $\left.\mathrm{P}_{3}\right)$, (b) transmission rate $\left(\mathrm{E}_{1}, \mathrm{E}_{2}, \mathrm{E}_{3}\right)$, and (c) time segment load $\left(\mathrm{P}_{1} * \mathrm{E}_{1}\right)$, respectively. The overall early transmission rate $\left(\mathrm{E}_{1}\right)$ for D.C. is 0.049 ( $\mathrm{SD}=0.023)$, and the early transmission duration of 12.88 days $(\mathrm{SD}=10.25)$. The means and $\mathrm{SD}$ for the rate of change coefficient $\left(\mathrm{E}_{\mathrm{i}}\right)$, time point/duration $\left(\mathrm{P}_{\mathrm{i}}\right.$, days), and the time segment load $\left(\mathrm{P}_{\mathrm{i}}{ }^{*} \mathrm{E}_{\mathrm{i}}\right)$ for transmission and mortality for D.C. ward level are presented in supplementary table 1 .

Table 2 Summary of association between COVID-19 early dynamics and race/ethnicity, age, and ADI in D.C. ward level

\begin{tabular}{|c|c|c|c|c|c|c|c|c|c|}
\hline & \multicolumn{3}{|c|}{ Cross sectional } & \multirow{2}{*}{\multicolumn{3}{|c|}{$\begin{array}{l}\text { Transmission } \\
\text { Correlation value (r) } \\
\text { (p-value) }\end{array}$}} & \multirow{2}{*}{\multicolumn{3}{|c|}{$\begin{array}{l}\text { Mortality } \\
\text { Correlation value (r) } \\
\text { (p-value) }\end{array}$}} \\
\hline & \multirow{2}{*}{$\begin{array}{l}\text { Confirmed } \\
\text { cases }(100,000)\end{array}$} & \multirow{2}{*}{$\begin{array}{l}\text { Death } \\
(100,000)\end{array}$} & \multirow[t]{2}{*}{ Case fatality rate } & & & & & & \\
\hline & & & & E1 & P1 & P1*E1 & E1 & P1 & P1*E1 \\
\hline $\begin{array}{l}\text { Social determinant } \\
\text { (ADI) }\end{array}$ & $\begin{array}{l}0.54 \\
0.1697\end{array}$ & $\begin{array}{l}0.83 \\
0.0100\end{array}$ & $\begin{array}{l}0.28 \\
0.5089\end{array}$ & $\begin{array}{l}0.88 \\
0.0044\end{array}$ & $\begin{array}{l}-0.47 \\
0.2364\end{array}$ & $\begin{array}{l}0.37 \\
0.3718\end{array}$ & $\begin{array}{l}-0.30 \\
0.4691\end{array}$ & $\begin{array}{l}0.21 \\
0.6236\end{array}$ & $\begin{array}{l}-0.17 \\
0.6805\end{array}$ \\
\hline $\begin{array}{l}\text { Long-term care } \\
\text { facilities }\end{array}$ & $\begin{array}{l}-0.26 \\
0.5395\end{array}$ & $\begin{array}{l}0.09 \\
0.8259\end{array}$ & $\begin{array}{l}0.68 \\
0.0655\end{array}$ & $\begin{array}{l}-0.015 \\
0.9722\end{array}$ & $\begin{array}{l}0.004 \\
0.9925\end{array}$ & $\begin{array}{l}0.10 \\
0.8111\end{array}$ & $\begin{array}{l}-0.20 \\
0.6348\end{array}$ & $\begin{array}{l}0.44 \\
0.2811\end{array}$ & $\begin{array}{l}-0.12 \\
0.7832\end{array}$ \\
\hline $\begin{array}{l}\text { Long-term capacity } \\
\text { (Beds) }\end{array}$ & $\begin{array}{l}0.11 \\
0.7948\end{array}$ & $\begin{array}{l}0.50 \\
0.2022\end{array}$ & $\begin{array}{l}0.49 \\
0.2135\end{array}$ & $\begin{array}{l}0.44 \\
0.2749\end{array}$ & $\begin{array}{l}-0.20 \\
0.6252\end{array}$ & $\begin{array}{l}0.31 \\
0.4532\end{array}$ & $\begin{array}{l}-0.22 \\
0.5979\end{array}$ & $\begin{array}{l}0.38 \\
0.3486\end{array}$ & $\begin{array}{l}-0.12 \\
0.7746\end{array}$ \\
\hline \multicolumn{10}{|l|}{ Race/Ethnicity } \\
\hline African American/Black & $\begin{array}{l}0.66 \\
0.0739\end{array}$ & $\begin{array}{l}0.89 \\
0.0029\end{array}$ & $\begin{array}{l}0.13 \\
0.7652\end{array}$ & $\begin{array}{l}0.86 \\
0.0068\end{array}$ & $\begin{array}{l}-0.54 \\
0.1629\end{array}$ & $\begin{array}{l}0.24 \\
0.5747\end{array}$ & $\begin{array}{l}-0.38 \\
0.3484\end{array}$ & $\begin{array}{l}0.11 \\
0.7926\end{array}$ & $\begin{array}{l}-0.35 \\
0.3963\end{array}$ \\
\hline Whites & $\begin{array}{l}-0.77 \\
0.0265\end{array}$ & $\begin{array}{l}-0.93 \\
0.0009\end{array}$ & $\begin{array}{l}0.02 \\
0.9613\end{array}$ & $\begin{array}{l}-0.88 \\
0.0041\end{array}$ & $\begin{array}{l}0.58 \\
0.1315\end{array}$ & $\begin{array}{l}-0.18 \\
0.6757\end{array}$ & $\begin{array}{l}0.34 \\
0.4135\end{array}$ & $\begin{array}{l}0.007 \\
0.9862\end{array}$ & $\begin{array}{l}0.35 \\
0.3934\end{array}$ \\
\hline Asian & $\begin{array}{l}-0.80 \\
0.0174\end{array}$ & $\begin{array}{l}-0.93 \\
0.0007\end{array}$ & $\begin{array}{l}-0.004 \\
0.9924\end{array}$ & $\begin{array}{l}-0.90 \\
0.0022\end{array}$ & $\begin{array}{l}0.74 \\
0.0373\end{array}$ & $\begin{array}{l}0.0040 \\
0.9931\end{array}$ & $\begin{array}{l}0.54 \\
0.1651\end{array}$ & $\begin{array}{l}-0.07 \\
0.8698\end{array}$ & $\begin{array}{l}0.57 \\
0.1437\end{array}$ \\
\hline Latino & $\begin{array}{l}0.31 \\
0.4488\end{array}$ & $\begin{array}{l}-0.16 \\
0.7099\end{array}$ & $\begin{array}{l}-0.82 \\
0.0130\end{array}$ & $\begin{array}{l}-0.17 \\
0.6838\end{array}$ & $\begin{array}{l}-0.077 \\
0.8561\end{array}$ & $\begin{array}{l}-0.50 \\
0.2106\end{array}$ & $\begin{array}{l}0.29 \\
0.4844\end{array}$ & $\begin{array}{l}-0.63 \\
0.0975\end{array}$ & $\begin{array}{l}0.03 \\
0.9412\end{array}$ \\
\hline \multicolumn{10}{|l|}{ Age (years) } \\
\hline $0-17$ & $\begin{array}{l}0.67 \\
0.0709\end{array}$ & $\begin{array}{l}0.87 \\
0.0046\end{array}$ & $\begin{array}{l}0.23 \\
0.5816\end{array}$ & $\begin{array}{l}0.91 \\
0.0019\end{array}$ & $\begin{array}{l}-0.69 \\
0.0563\end{array}$ & $\begin{array}{l}0.10 \\
0.8057\end{array}$ & $\begin{array}{l}-0.61 \\
0.1099\end{array}$ & $\begin{array}{l}0.26 \\
0.5289\end{array}$ & $\begin{array}{l}-0.52 \\
0.1880\end{array}$ \\
\hline $18-24$ & $\begin{array}{l}-0.62 \\
0.1005\end{array}$ & $\begin{array}{l}-0.45 \\
0.2692\end{array}$ & $\begin{array}{l}0.49 \\
0.2125\end{array}$ & $\begin{array}{l}-0.43 \\
0.2864\end{array}$ & $\begin{array}{l}0.75 \\
0.0337\end{array}$ & $\begin{array}{l}0.59 \\
0.1215\end{array}$ & $\begin{array}{l}0.55 \\
0.1560\end{array}$ & $\begin{array}{l}0.083 \\
0.8433\end{array}$ & $\begin{array}{l}0.76 \\
0.0271\end{array}$ \\
\hline $65+$ & $\begin{array}{l}0.25 \\
0.5517\end{array}$ & $\begin{array}{l}0.13 \\
0.7534\end{array}$ & $\begin{array}{l}0.071 \\
0.8676\end{array}$ & $\begin{array}{l}0.010 \\
0.9805\end{array}$ & $\begin{array}{l}-0.31 \\
0.4495\end{array}$ & $\begin{array}{l}-0.48 \\
0.2316\end{array}$ & $\begin{array}{l}-0.35 \\
0.3939\end{array}$ & $\begin{array}{l}-0.14 \\
0.7465\end{array}$ & $\begin{array}{l}-0.49 \\
0.2229\end{array}$ \\
\hline
\end{tabular}

$r$, correlation value; $n s$, not significant at $p$-value $=p<0.05$; red highlight is significant, and green is tendency; $E_{l}$, coefficient/slope; $P_{l}$, duration, inflection time point (days); $P_{l} * E_{l}$, time segment load 
Table 3 Summary of association between COVID-19 early and race/ethnicity, age, and ADI in Washington, D.C., and adjacent counties (county/ district level)

\begin{tabular}{|c|c|c|c|c|c|c|c|c|c|}
\hline & \multirow{2}{*}{$\begin{array}{l}\text { Confirmed cases } \\
\text { (Correlation value) } \\
\text { P-value }\end{array}$} & \multirow[t]{2}{*}{ Deaths per 100,000} & \multirow{2}{*}{$\begin{array}{l}\text { Case fatality per } \\
100,000\end{array}$} & \multicolumn{3}{|c|}{ Transmission } & \multicolumn{3}{|c|}{ Mortality } \\
\hline & & & & $\mathrm{P} 1$ & E1 & $\mathrm{P} 1 * \mathrm{E} 1$ & $\mathrm{P} 1$ & E1 & P1*E1 \\
\hline Social determinant (ADI) & $\begin{array}{l}0.82 \\
0.0437\end{array}$ & $\begin{array}{l}0.22 \\
0.6810\end{array}$ & $\begin{array}{l}-0.45 \\
0.3729\end{array}$ & $\begin{array}{l}0.58 \\
0.2249\end{array}$ & $\begin{array}{l}-0.19 \\
0.7177\end{array}$ & $\begin{array}{l}0.28 \\
0.5896\end{array}$ & $\begin{array}{l}0.67 \\
0.1448\end{array}$ & $\begin{array}{l}0.68 \\
0.1344\end{array}$ & $\begin{array}{l}0.96 \\
0.0029\end{array}$ \\
\hline $\begin{array}{l}\text { Long-term capacity } \\
\text { (Beds) }\end{array}$ & $\begin{array}{l}0.49 \\
0.3203\end{array}$ & $\begin{array}{l}0.78 \\
0.0671\end{array}$ & $\begin{array}{l}0.27 \\
0.6001\end{array}$ & $\begin{array}{l}-0.13 \\
0.7960\end{array}$ & $\begin{array}{l}-0.34 \\
0.5143\end{array}$ & $\begin{array}{l}-0.35 \\
0.5007\end{array}$ & $\begin{array}{l}-0.08 \\
0.8716\end{array}$ & $\begin{array}{l}0.01 \\
0.9810\end{array}$ & $\begin{array}{l}0.11 \\
0.8389\end{array}$ \\
\hline Long-term care facilities & $\begin{array}{l}0.28 \\
0.5964\end{array}$ & $\begin{array}{l}0.66 \\
0.1506\end{array}$ & $\begin{array}{l}0.33 \\
0.5262\end{array}$ & $\begin{array}{l}-0.19 \\
0.7200\end{array}$ & $\begin{array}{l}-0.42 \\
0.4095\end{array}$ & $\begin{array}{l}-0.49 \\
0.3219\end{array}$ & $\begin{array}{l}-0.34 \\
0.5129\end{array}$ & $\begin{array}{l}-0.06 \\
0.9045\end{array}$ & $\begin{array}{l}-0.09 \\
0.8726\end{array}$ \\
\hline \multicolumn{10}{|l|}{ Race/Ethnicity } \\
\hline African American/Black & $\begin{array}{l}0.80 \\
0.0537\end{array}$ & $\begin{array}{l}0.53 \\
0.2745\end{array}$ & $\begin{array}{l}-16.1 \\
0.7612\end{array}$ & $\begin{array}{l}0.48 \\
0.3343\end{array}$ & $\begin{array}{l}-0.37 \\
0.4729\end{array}$ & $\begin{array}{l}-0.025 \\
0.9620\end{array}$ & $\begin{array}{l}0.46 \\
0.3566\end{array}$ & $\begin{array}{l}0.64 \\
0.1693\end{array}$ & $\begin{array}{l}0.84 \\
0.0345\end{array}$ \\
\hline Non-Hispanic Whites & $\begin{array}{l}-0.89 \\
\mathbf{0 . 0 1 8 7}\end{array}$ & $\begin{array}{l}-0.60 \\
0.2123\end{array}$ & $\begin{array}{l}0.20 \\
0.7102\end{array}$ & $\begin{array}{l}-0.26 \\
0.6105\end{array}$ & $\begin{array}{l}0.19 \\
0.7155\end{array}$ & $\begin{array}{l}-0.17 \\
0.7483\end{array}$ & $\begin{array}{l}-0.56 \\
0.2512\end{array}$ & $\begin{array}{l}-0.34 \\
0.5079\end{array}$ & $\begin{array}{l}-0.66 \\
0.1507\end{array}$ \\
\hline Asian & $\begin{array}{l}-0.53 \\
0.2826\end{array}$ & $\begin{array}{l}-0.24 \\
0.6429\end{array}$ & $\begin{array}{l}0.14 \\
0.7912\end{array}$ & $\begin{array}{l}-0.49 \\
0.3277\end{array}$ & $\begin{array}{l}0.30 \\
0.5644\end{array}$ & $\begin{array}{l}0.12 \\
0.8198\end{array}$ & $\begin{array}{l}-0.28 \\
0.5890\end{array}$ & $\begin{array}{l}-0.75 \\
0.0849\end{array}$ & $\begin{array}{l}-0.82 \\
0.0480\end{array}$ \\
\hline Latino & $\begin{array}{l}0.53 \\
0.2814\end{array}$ & $\begin{array}{l}0.42 \\
0.4124\end{array}$ & $\begin{array}{l}-0.05 \\
0.9217\end{array}$ & $\begin{array}{l}-0.62 \\
0.1914\end{array}$ & $\begin{array}{l}0.50 \\
0.3107\end{array}$ & $\begin{array}{l}0.48 \\
0.3328\end{array}$ & $\begin{array}{l}0.37 \\
0.4752\end{array}$ & $\begin{array}{l}-0.64 \\
0.1752\end{array}$ & $\begin{array}{l}-0.22 \\
0.6758\end{array}$ \\
\hline \multicolumn{10}{|l|}{ Age (years) } \\
\hline $0-17$ & $\begin{array}{l}0.34 \\
0.5144\end{array}$ & $\begin{array}{l}0.095 \\
0.8578\end{array}$ & $\begin{array}{l}-0.23 \\
0.6591\end{array}$ & $\begin{array}{l}-0.48 \\
0.3311\end{array}$ & $\begin{array}{l}0.51 \\
0.3059\end{array}$ & $\begin{array}{l}0.63 \\
0.1789\end{array}$ & $\begin{array}{l}0.39 \\
0.4507\end{array}$ & $\begin{array}{l}-0.69 \\
0.1317\end{array}$ & $\begin{array}{l}-0.31 \\
0.5450\end{array}$ \\
\hline $18-24$ & $\begin{array}{l}0.07 \\
0.8907\end{array}$ & $\begin{array}{l}0.65 \\
0.1598\end{array}$ & $\begin{array}{l}0.57 \\
0.2417\end{array}$ & $\begin{array}{l}-0.22 \\
0.6666\end{array}$ & $\begin{array}{l}0.29 \\
0.5735\end{array}$ & $\begin{array}{l}-0.0005 \\
0.9992\end{array}$ & $\begin{array}{l}0.34 \\
0.5037\end{array}$ & $\begin{array}{l}-0.17 \\
0.7545\end{array}$ & $\begin{array}{l}-0.04 \\
0.9437\end{array}$ \\
\hline 65 & $\begin{array}{l}0.19 \\
0.7240\end{array}$ & $\begin{array}{l}0.49 \\
0.3196\end{array}$ & $\begin{array}{l}0.22 \\
0.6797\end{array}$ & $\begin{array}{l}-0.21 \\
0.6832\end{array}$ & $\begin{array}{l}-0.27 \\
0.5979\end{array}$ & $\begin{array}{l}-0.27 \\
0.6054\end{array}$ & $\begin{array}{l}-0.23 \\
0.6625\end{array}$ & $\begin{array}{l}-0.24 \\
0.6411\end{array}$ & $\begin{array}{l}-0.22 \\
0.6730\end{array}$ \\
\hline
\end{tabular}

There is statistically significant disparity in the transmission $\mathrm{E}_{1}$ and $\mathrm{P}_{1}(p=.0093)$ at the ward level. Ward 8 had the highest (0.085) early transmission rate $\mathrm{E}_{1}$, and the lowest early transmission $\mathrm{E}_{1}$ was observed in ward 2 (0.018). In terms of time point or transmission duration, ward 2 had the longest early transmission duration of 36 days, where wards 1, 4, 5, 7 , and 8 recorded the shortest early transmission duration of 7 days each.

The initial mortality rate $\left(\mathrm{E}_{1}\right)$ for D.C. was $0.089(\mathrm{SD}=$ $0.069)$. Ward 2 has the highest early mortality rate $(0.23)$, and the lowest rate was found in ward $6(0.02)$. In addition, for mortality duration $\left(\mathrm{P}_{1}\right)$, ward 5 had the shortest early mortality duration of 8 days, whereas ward 6 reported the longest (27 days).

\section{ADI and COVID-19 Disease Early Transmission Dynamics and} Mortality Table 2 presents the association between ADI and transmission and mortality time point $\left(\mathrm{P}_{1}\right)$, rate exponential constant $\left(\mathrm{E}_{1}\right)$, and time segment load $\left(\mathrm{P}_{1} * \mathrm{E}_{1}\right)$ for D.C. ward level. Our results show that initial COVID-19 transmission rate, $\mathrm{E}_{1}$, is associated with ADI score. There was statistically significant positive association between ADI and COVID19 early transmission rate $\left(\mathrm{E}_{1} ; 95 \% \mathrm{CI}=0.55,0.98, p=\right.$ 0.0019). Generally, a higher ADI score was associated with higher COVID-19 transmission rate $\mathrm{E}_{1}$. The early transmission rate $\left(\mathrm{E}_{1}\right)$ was higher in more socially disadvantages wards (i.e., wards with high ADI scores). The D.C. wards 4,
5, 7, and 8 have a higher initial transmission rate for COVID19 , and these wards lack resources. Additionally, wards 7 and 8 have high ADI scores and have greater majority of African Americans compared to Whites. In terms of time segment load of mortality, there was no association with ADI. We observed higher risk of COVID-19 transmission dynamics and disease burden in socially disadvantage geographic areas (in terms of ADI). Our study results demonstrate that ADI has an impact on COVID-19 transmission but not mortality in the District of Columbia.

Age and COVID-19 Disease Early Transmission Dynamics and Mortality Table 2 presents the associations between age structure and COVID-19 disease early transmission and mortality dynamics at D.C. ward level. There is statistically significant positive association between $0-17$ age group and initial transmission rate $\left(\mathrm{E}_{1}\right)(95 \% \mathrm{CI}=$ $0.56-0.98 ; r=0.91 ; p=.0019)$. Initial transmission rate $\left(\mathrm{E}_{1}\right)$ has no statistically significant relation with age groups $18-24$ or 65 . The transmission duration $\mathrm{P}_{1}$ is only associated with age group $18-24$ (95\% CI $=0.09-0.95$; $r=0.75 ; p=.0337)$. There was no relationship between mortality and age. Similar results were found for second transmission rate $\left(\mathrm{P}_{2}, \mathrm{E}_{2}, \mathrm{P}_{2} * \mathrm{E}_{2}\right)$ and third transmission rate $\left(\mathrm{P}_{3}, \mathrm{E}_{3}\right.$, and $\left.\mathrm{P}_{3} * \mathrm{E}_{3}\right)$ as provided in supplementary tables 3 and 4 . 

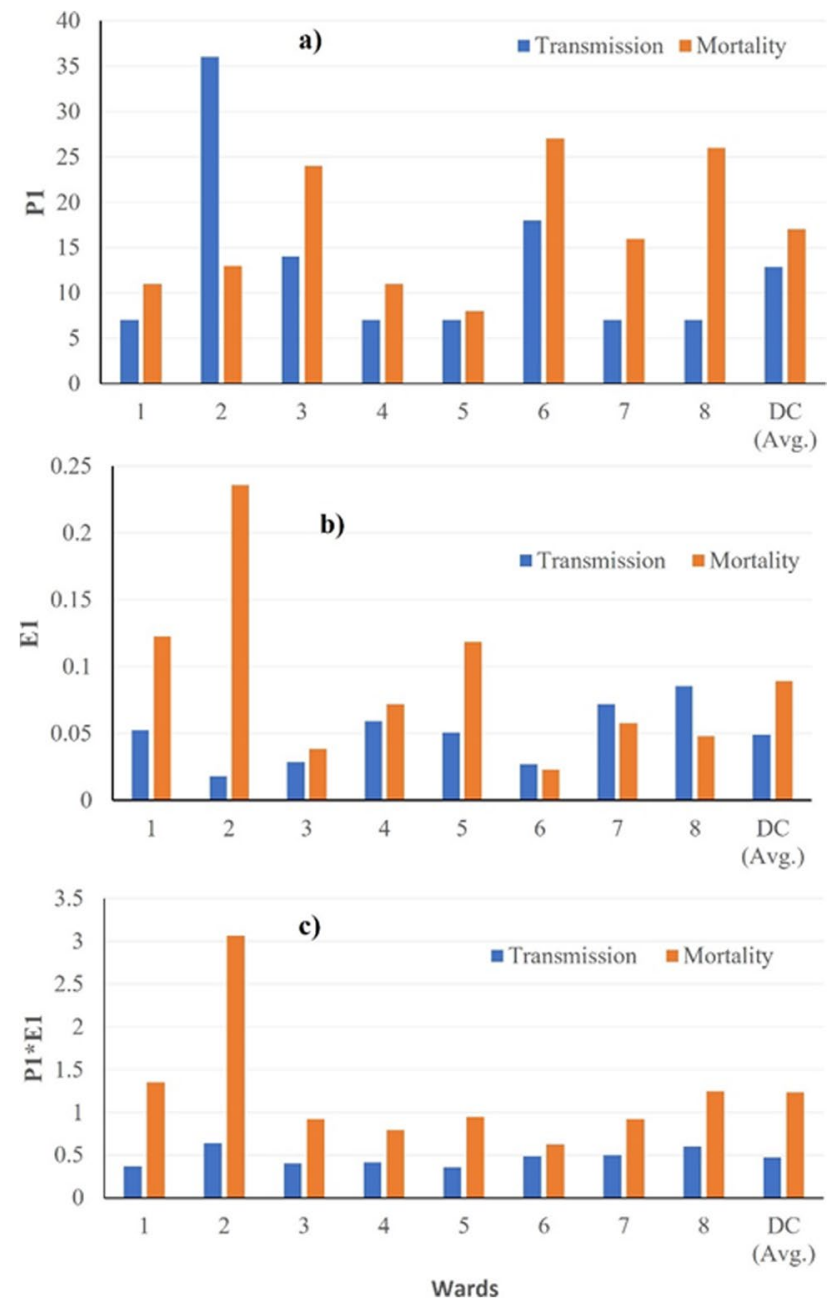

Fig. 2 Geographic distribution of COVID-19 transmission and mortality outcome variables by a length (days $\left.\mathrm{P}_{1}\right)$, b rate $\left(\mathrm{E}_{1}\right)$, and $\mathbf{c}$ time segment load $\left(\mathrm{P}_{1} * \mathrm{E}_{1}\right)$ in D.C. ward level

Race/Ethnicity and COVID-19 Outcomes There is significant positive association between initial transmission rate $\mathrm{E}_{1}$ and race/ethnicity: AA $(r=0.86, p=.0068)$, non-Hispanic Whites $(95 \% \mathrm{CI}=-0.97$ to $-0.46 ; r=-0.88 ; p=.0041)$, and Asians ( $95 \% \mathrm{CI}=-0.98$ to $-0.54 ; r=0.90 ; p=.0022)$ (Table 3). However, there is no relation between Latino and initial transmission rate $\left(\mathrm{E}_{1}\right)$. For transmission duration $\mathrm{P}_{1}$, the only association was identified with Asian population (95\% $\mathrm{CI}=0.07$ to $-0.95 ; r=0.74 ; p=.0373)$ as shown in Table 2. There is a positive correlation between Asian population and transmission duration $\left(\mathrm{P}_{1}\right)$ at D.C. ward level. This may be because of their contact patterns or less adherence to mitigation strategies. Ward 8 has the highest initial transmission rate $\left(\mathrm{E}_{1}\right)$ and ward 2 has the lowest. The highest transmission duration, $\mathrm{P}_{1}$, is observed in ward 2 (36 days), and the least duration (7 days) in wards $1,4,5,7$, and 8. Also, ward 8 has the most AA population (92.06\%), and ward 3 has the least (5.39\%). Ward 3 has most non-Hispanic Whites
(81.49\%), and ward 7 has the least (2.97\%). There was no relationship between mortality and race/ethnicity.

Cross-sectional Analysis Results The geographic distribution of COVID-19 laboratory confirmed case, deaths per 100,000 , and case fatality rate of Washington, D.C., at ward level and adjacent counties in Virginia and Maryland is presented in Table 1. As of July 4th, 2020, Washington, D.C., had reported a 10,311 total COVID-19 cases (1446 cases per 100,000), and 425 deaths (59 deaths per 100,000). All the 8 geographically assigned wards have reported cases of COVID-19. Ward 4 had the highest total confirmed cases $(24,580$ per 100,000$)$, but ward 8 had the highest recorded deaths $(141$ per 100,000$)$. The highest case fatality rate of $6.6 \%$ was recorded in ward 3. Comparing D.C. to the adjacent counties in Virginia and Maryland, Prince George's County (MD) had higher number of confirmed cases (2192 per 100,000) and deaths (77 per 100,0000) compared to D.C. (59 per 100,000$)$. Alexandria City, VA, had the least case fatality rate $(2.4 \%)$, and highest rate was recorded in Arlington County (5.2\%). The means and SD for the rate of change coefficient $\left(\mathrm{E}_{\mathrm{i}}\right)$, time point/duration $\left(\mathrm{P}_{\mathrm{i}}\right.$, days), and the time segment load $\left(\mathrm{P}_{\mathrm{i}} * \mathrm{E}_{\mathrm{i}}\right)$ for transmission and mortality for D.C. and adjacent counties are presented (supplementary table 2). Table 3 presents the associations between age structure and COVID-19 disease early transmission and mortality dynamics at D.C./adjacent county level. There was significant positive association between ADI and COVID19 confirmed cases per 100,000 ( $r=0.82, p=0.0437)$. Non-Hispanic White population was negatively associated with COVID-19 confirmed cases per 100,000 ( $r=-0.89$, $p=0.0187$ ). However, there was no relationship between all the predictors and COVID-19 early transmission outcome variables $\left(\mathrm{P}_{1}, \mathrm{E}_{1}\right.$, and $\left.\mathrm{P}_{1} * \mathrm{E}_{1}\right)$, deaths per 100,000 , and case fatality rate as shown in Table 3 . We observed an association between COVID-19 mortality outcome variable $\left(\mathrm{P}_{1} * \mathrm{E}_{1}\right)$ and ADI $(r=0.96, p=0.0029)$, race AA $(r=0.84, p=0.0345)$, and Asian $(r=-0.82, p=0.0480)$.

\section{Multiple Regression Model}

Table 4 presents multiple linear regression analysis of socioeconomic and demographic factors and COVID-19 transmission outcome variables rate $E_{1}$ and duration $P_{1}$. For transmission rate $\mathrm{E}_{1}$, the significant predictors/covariates to the regression model were ADI (CI: 0.009-0.014; $p=0.0006$ ), age $0-17$ (CI: $0.0028-0.004 ; p=0.0041$ ), race AA (CI: -0.0022 to $-0.0014 ; p=0.0006)$, and race nonHispanic Whites (CI: -0.0015 to $-0.0008 ; p=0.0018$ ). However, Asian $(p=0.1045)$ was not significant predictor in the multiple regression model. The best fitted multiple linear regression model for transmission $E_{1}$ is shown below: 
Transmission $\mathrm{E}_{1}(y)=0.047+0.01(\mathrm{ADI})+0.003(\mathrm{Age}$ $0-17)-0.0018$ (Race AA) -0.0011 (Non-Hispanic Whites). The accuracy of the model is $99.6642 \%$ (i.e., $\mathrm{R} 2=0.998561$, and adjusted $\mathrm{R} 2=0.996642$ ).

For the transmission duration $\mathrm{P}_{1}$, the significant predictors observed were Asian ( $p=0.0144$; CI: 5.53-23.73) and non-Hispanic Whites ( $p=0.0200 ; \mathrm{CI}$ : -2.52 to -0.44 ). However, age $0-17(p=0.1145)$ and ADI $(p=0.0673)$ were not significant predictors in the multivariable regression model for $\mathrm{P}_{1}$. The best fitted multiple linear regression model for transmission $P_{1}$ is shown below:

Transmission $\mathrm{P}_{1}(y)=12.68+14.63($ Asian $)-1.48$

(Non-Hispanic Whites) - 6.28 (ADI) + 1.76 (Age 0-17)

The accuracy of the regression model is $87.78 \%$ (i.e., $R^{2}=0.9476$, and adjusted $R^{2}=0.8778$ ).

\section{Discussion}

In this study, we determined the effects of area deprivation index (ADI, a measure of social determinant) and demographic factors (age and race/ethnicity) on COVID-19 disease early transmission dynamics and burden (morbidity and mortality) in Washington, D.C. We demonstrated that early transmission is highly correlated with racial/ethnic composition, age structure, and the social determinants (as measured by ADI) of the Washington, D.C. community, and our findings support previous studies (e.g., [5]). Various studies on COVID-19 disease show that many US populations that were previously known to bear the consequences of disparities in health outcomes are now experiencing the additional burden of disproportionate COVID-19 disease morbidity and mortality. These vulnerable populations share several social determinants of health ( $\mathrm{SDoH})$. Using ADI, as measure of SDoH, we observed a great disparity in ADI among wards in Washington, D.C. Our findings also showed significant positive association between ADI and COVID-19 early transmission rate. Our results support recent study findings by Madhav et al. [23] in Louisiana state that ADI affects COVID-19 risk at the granular neighborhood environment level. Area depravation index (ADI) as a measure of social determinants considers income, education, employment, and housing quality [10]. Systemic inequities in health, social status, and income contribute to increased risk of COVID-19 transmission in deprived neighborhoods $[6,24]$. The D.C. wards 7 and 8 with higher ADI score (more-disadvantaged neighborhood) also recorded higher initial transmission rate for COVID-19, which may be due to their lack of resources. Other studies also show that in low-income or deprived regions, higher COVID-19 incidence, and mortality have been observed [25-27]. Recent findings by Bilal et al. [26] reported a $36 \%$ increased incidence of COVID-19 in less deprived neighborhoods.

Racial/ethnic distribution has been reported as a major moderating factor in COVID-19 disease. Our findings demonstrated positive association between initial transmission rate $\mathrm{E}_{1}$ and African American population in D.C. This result suggests African Americans are at higher risk of increased initial disease transmission rate which support previous findings by Raifman and Raifman [28]. This situation is likely because African American/Blacks and other vulnerable minority population live in low-income regions coupled by structural disparities in wealth, medical insurance, facilities, and others [29]. Furthermore, African Americans are more likely to have chronic medical conditions such as hypertension, diabetes, heart disease, and

Table 4 Multiple linear regression analysis of socioeconomic and demographic factors and COVID-19 transmission outcome variables in D.C. ward level

\begin{tabular}{|c|c|c|c|c|c|c|c|c|c|c|c|c|}
\hline \multirow[t]{3}{*}{ Predictor variables } & \multicolumn{6}{|c|}{ Transmission $\mathrm{E}_{1}$} & \multicolumn{6}{|c|}{ Transmission $\mathrm{P}_{1}$} \\
\hline & \multicolumn{2}{|c|}{$\begin{array}{l}\text { Standardized coef- } \\
\text { ficient }\end{array}$} & \multirow[t]{2}{*}{$t$ value } & \multirow[t]{2}{*}{$p$} & \multicolumn{2}{|l|}{$95 \%$ CI } & \multicolumn{2}{|c|}{$\begin{array}{l}\text { Standardized } \\
\text { coefficient }\end{array}$} & \multirow[t]{2}{*}{$t$ value } & \multirow[t]{2}{*}{$p$} & \multicolumn{2}{|l|}{$95 \%$ CI } \\
\hline & Beta & SE & & & Lower & Upper & Beta & SE & & & Lower & Upper \\
\hline ADI & 0.012 & 0.0008 & 26.47 & $0.0006^{*}$ & 0.009 & 0.014 & -6.28 & 2.24 & -2.81 & $0.0673^{\mathrm{ns}}$ & -13.41 & 0.83 \\
\hline \multicolumn{13}{|l|}{ Race } \\
\hline AA & -0.0018 & 0.0001 & -15.37 & $0.0006^{*}$ & -0.0022 & -0.0014 & - & - & - & - & - & - \\
\hline NH Whites & -0.0011 & 0.0011 & -10.55 & $0.0018^{*}$ & -0.0015 & -0.0008 & -1.48 & 0.33 & 4.54 & $0.0200^{*}$ & -2.5 & -0.44 \\
\hline Asian & - & - & - & - & - & - & 14.63 & 2.86 & 5.12 & $0.0144^{*}$ & 5.5 & 23.73 \\
\hline \multicolumn{13}{|l|}{ Age } \\
\hline $0-17$ & 0.003 & 0.0002 & 16.79 & $0.0005^{*}$ & 0.0028 & 0.0041 & & & & & & \\
\hline
\end{tabular}

Note: *statistically significant at $\mathrm{p}<0.05$, ns is not significant at $\mathrm{p}<0.05$. 
obesity, which are related to increased risk of illness from COVID-19. Additionally, African Americans also usually live in crowded housing, work at crowed workplace/ worksite, and are more likely to rely on public transportation that exposes them to an increased risk for COVID-19 disease [30,31]. On the other hand, our findings showed no association between mortality and other race/ethnicity except Latinos/Hispanics. Most of recent studies found that African Americans comprise higher proportion of deaths relative to their percentage in those jurisdictions' population [32]. In contrast with Egbert [32] study, we found no association between AA population and disease mortality for Washington, D.C., during early transmission period.

For Washington, D.C., our findings were contrary to previous studies that found 65 -and-older group has higher risk of disease transmission rate and mortality [33, 34]. A study by Wu et al. [33] reported that in Wuhan, China (where the disease was first reported), ages below 30 and above 59 have higher mortality rate when they develop symptoms of the disease. Although some previous studies have shown that children and young adults (ages 0-17 years) are susceptible to the SARS-CoV-2 infection, very few studies have focused on the potential severity of the disease in the younger age group. In the current study, we found a strong positive association between age (0-17 years) and confirmed cases (per 100,000), early transmission rate $\left(E_{1}\right)$, and deaths (per 100,000). Our results support the finding of DeBiasi et al. [35] that highlighted the potential COVID-19 severity in pediatric population (0-15 years) in Washington, D.C.

In summary, we observed a great disparity in area deprivation index among Washington, D.C. wards. There is high variability in early transmission across the geographic regions of Washington, D.C. (neighborhood), and this variability is driven by race/ethnic composition and social determinants (as measured by ADI). Mortality on the other hand is not correlated with race, age, and ADI at community-wide population. This may enable better interpreting the pandemic trajectory in terms of social risk factors in Washington, D.C.

Supplementary Information The online version contains supplementary material available at https://doi.org/10.1007/s40615-022-01238-1.

Funding The project described was supported by the National Center for Advancing Translational Sciences (NCATS), National Institutes of Health, through Grant Award Number UL1TR002489.

\section{Declarations}

Ethics Approval Not applicable

Consent to Participate Not applicable
Conflict of Interest Not applicable

Disclaimer The content is solely the responsibility of the authors and does not necessarily represent the official views of NIH.

\section{References}

1. Du HG. COVID-19 Dashboard by The Center for Systems Science and Engineering at John Hopkins University. 2020 [cited 2020; Available from: https://gisanddata.maps.arcgis.com/apps/opsda shboard/index.html\#/bda7594740fd40299423467b48e9ecf6.

2. Shereen MA, et al. COVID-19 infection: origin, transmission, and characteristics of human coronaviruses. J Adv Res. 2020;24:91-8. https://doi.org/10.1016/j.jare.2020.03.005.

3. Abrams EM, Szefler SJ. COVID-19 and the impact of social determinants of health. Lancet Respir Med. 2020;8(7):659-61. https:// doi.org/10.1016/S2213-2600(20)30234-4.

4. Harlem G, Lynn M. Descriptive analysis of social determinant factors in urban communities affected by COVID-19. J Public Health (Oxf). 2020. https://doi.org/10.1093/pubmed/fdaa078.

5. Yancy CW. COVID-19 and african americans. Jama. 2020;323(19):1891-2. https://doi.org/10.1001/jama.2020.6548.

6. Coronavirus Disease 2019 (COVID-19). Centers for Disease Control and Prevention. Available at: https://www.cdc.gov/coron avirus/2019-ncov/need-extra-precautions/racial-ethnic-minorities. html. Published 2020. Accessed 4 June 2020.

7. Tai DBG, Shah A, Doubeni CA, Sia IG, Wieland ML. The disproportionate impact of COVID-19 on racial and ethnic minorities in the United States. Clin Infect Dis. 2021;72(4):703-6.

8. Heyman JC, Kelly PL, Reback GM, Blumenstock KH (2018). Social determinants of health. Health and social work: practice, policy, and research; Edited by Springer Publ.

9. HER DC, 2020

10. Wisconsin, U.o. Neighborhood Atlas. 2020; Available from: https://www.neighborhoodatlas.medicine.wisc.edu/.

11. Townsend P. Deprivation. J Soc Policy. 1987;16(2):125-46. https://doi.org/10.1017/S0047279400020341.

12. Butler DC, Petterson S, Phillips RL, Bazemore AW. Measures of social deprivation that predict health care access and need within a rational area of primary care service delivery. Health Serv Res. 2013;48(2pt1):539_ 59. https://doi.org/10.1111/j.1475-6773.2012.01449.x.

13. Matters DH. 2020 Demographics. 2020 [cited 2020; Available from: https://www.dchealthmatters.org/index.php?module= demographicdata\&controller=index\&action=index

14. Kind AJ, Jencks S, Brock J, Yu M, Bartels C, Ehlenbach W, Smith M. Neighborhood socioeconomic disadvantage and 30-day rehospitalization: a retrospective cohort study. Ann Intern Med. 2014;161(11):765-74. https://doi.org/10.7326/M13-2946.

15. Oluyomi AO, Gunter SM, Leining LM, Murray KO, Amos C. COVID-19 community incidence and associated neighborhoodlevel characteristics in Houston, Texas, USA. Int J Environ Res Public Health. 2021;18(4):1495.

16. Braveman PA, Egerter SA, Mockenhaupt RE. Broadening the focus: the need to address the social determinants of health. Am J Prev Med. 2011;40(1):S4-S18.

17. Tchicaya A, Lorentz N, Leduc K, de Lanchy G. COVID-19 mortality with regard to healthcare services availability, health risks, and socio-spatial factors at department level in France: a spatial cross-sectional analysis. PLoS One. 2021;16(9):e0256857.

18. Knighton AJ, et al. Introduction of an area deprivation index measuring patient socioeconomic status in an integrated health system: implications for population health. EGEMS (Wash DC). 2016;4(3):1238. https://doi.org/10.13063/2327-9214.1238. 
19. Singh GK. Area deprivation and widening inequalities in US mortality, 1969-1998. Am J Public Health. 2003;93(7):1137-43.

20. Wei J, Zhou L. Model selection using modified AIC and BIC in joint modeling of paired functional data. Stat Probabil Lett. 2010;80(23-24):1918-24.

21. Vrieze SI. Model selection and psychological theory: a discussion of the differences between the Akaike information criterion (AIC) and the Bayesian information criterion (BIC). Psychol Methods. 2012;17(2):228. https://doi.org/10.1037/a0027127.

22. JMP® Version 14.1.0. SAS Institute Inc., Cary, NC, 1989-2019.

23. Madhav KC, Oral E, Straif-Bourgeois S, Rung AL, Peters ES. The effect of area deprivation on COVID-19 risk in Louisiana. PLoS One. 2020;15(12):e0243028. https://doi.org/10.1371/journ al.pone. 0243028 .

24. Borjas GJ. Demographic determinants of testing incidence and COVID-19 infections in New York City neighborhoods (No. w26952): National Bureau of Economic Research; 2020.

25. Carrion D, Colicino E, Pedretti NF, Arfer KB, Rush J, DeFelice N, Just AC. Assessing capacity to social distance and neighborhoodlevel health disparities during the COVID-19 pandemic. medRxiv. 2020. https://doi.org/10.1101/2020.06.02.20120790.

26. Bilal U, Barber S, Diez-Roux AV. Spatial inequities in COVID-19 outcomes in three us cities. medRxiv. 2020. https://doi.org/10. 1101/2020.05.01.20087833.

27. Plümper T, Neumayer E. The pandemic predominantly hits poor neighbourhoods? SARS-CoV-2 infections and COVID-19 fatalities in German districts. Eur J Pub Health. 2020;30(6):1176-80. https://doi.org/10.1093/eurpub/ckaa168.

28. Raifman MA, Raifman JR. Disparities in the population at risk of severe illness from COVID-19 by race/ethnicity and income. Am J Prev Med. 2020;59(1):137-9.
29. Griffith K, Evans L, Bor J. The Affordable Care Act reduced socioeconomic disparities in health care access. Health Aff (Millwood). 2017;36(8):1503-10. https://doi.org/10.1377/hlthaff.2017.0083.

30. Wang X, Fang X, Cai Z, Wu X, Gao X, Min J, et al. Comorbid chronic diseases 345 and acute organ injuries are strongly correlated with disease severity and mortality 346 among COVID-19 patients: a systemic review and meta-analysis. Research (Wash D 347 C). 2020;2020(2402961):348.

31. Liu H, Chen S, Liu M, Nie H, Lu H. Comorbid Chronic Diseases Are Strongly 349 Correlated With Disease Severity among COVID-19 Patients: A Systematic Review and 350 Meta-Analysis. Aging Dis. 2020;11(3):668-78.

32. Egbert A. COVID-19 deaths analyzed by race. APM Research Lab. Available at: https://www.apmresearchlab.org/covid/deathsby-race. Published 11 May 2020. Accessed 10 June 2020 APM Research Lab. (2020).

33. Wu JT, Leung K, Bushman M, Kishore N, Niehus R, de Salazar PM, Leung GM. Estimating clinical severity of COVID-19 from the transmission dynamics in Wuhan, China. Nat Med. 2020;26(4):506-10.

34. Liu K, Chen Y, Lin R, Han K. Clinical features of COVID-19 in elderly patients: a comparison with young and middle-aged patients. J Infect. 2020.

35. DeBiasi RL, Song X, Delaney M, Bell M, Smith K, Pershad J, Hanisch B. Severe COVID-19 in children and young adults in the Washington, DC metropolitan region. J Pediatr. 2020.

Publisher's Note Springer Nature remains neutral with regard to jurisdictional claims in published maps and institutional affiliations. 